\title{
DIP-COATING SENYAWA KALSIUM FOSFAT DARI BATU KAPUR BUKIT TUI DENGAN VARIASI RATIO MOL Ca/P MELALUI METODE SOL-GEL
}

\author{
Lia Anggresani \\ STIKES Harapan Ibu Jambi \\ Jl. Tarmizi Kabir No. 71 Pakuan Baru Thehok Jambi 36132 \\ e-mail: anggresani@yahoo.com
}

\begin{abstract}
Preparation of Dip-Coating Calcium Phosphate via sol-gel method using natural limestone Bukit Tui as calcium precursors and diammonium hydrogen phosphate as phosphorus precursors with various $\mathrm{Ca} / \mathrm{P}$ mol ratio has been investigated. Etanol was used as solvent and DEA (dietanolamine) as stabilizing agent. Powder were prepared by calcinated the sol at $950^{\circ} \mathrm{C}$. The results characterized by Fourier Transform Infra-red, X-Ray diffraction and Scanning Electron Microscopy. FTIR results showed that the vibration form was $\mathrm{PO}_{4}{ }^{3-}, \mathrm{P}_{2} \mathrm{O}_{7}{ }^{4-}, \mathrm{O}-\mathrm{H}$ and $\mathrm{CO}_{2}$. X-Ray Diffraction (XRD) patterns of powder with various $\mathrm{Ca} / \mathrm{P}$ mol ratio showed that the product of calcium phosphate was $\mathrm{Ca}_{2} \mathrm{P}_{2} \mathrm{O}_{7}$ and also found the hydroxyapatite $\mathrm{Ca}_{10}\left(\mathrm{PO}_{4}\right)_{6}(\mathrm{OH})_{2}$ in $\mathrm{Ca} / \mathrm{P}$ ratio mol 1,7. Scanning Electron Microscopy (SEM) images of powder calcium phosphate revealed that their morphology were spheric and homogen. The coating process was done at glass substrate with coating speed $20 \mathrm{~cm} / \mathrm{min}$ by calcinations at $400^{\circ} \mathrm{C}$. . X-Ray Diffraction (XRD) patterns of thin layer showed that the product was $\mathrm{Ca}_{2} \mathrm{P}_{2} \mathrm{O}_{7}$ and Scanning Electron Microscopy (SEM) images of thin layer revealed that their morphology were bulk.
\end{abstract}

Key words; natural limestone, calcium phosphate, hydroxyapatite, sol-gel, dip-coating

\section{PENDAHULUAN}

Pengembangan bahan biomaterial sintesis sebagai bahan rehabilitasi jaringan tulang dan gigi diharapkan dapat meningkatkan pertumbuhan sel-sel yang akan melanjutkan fungsi daur kehidupan jaringan yang digantikan. Salah satu bahan yang sedang dikembangkan sebagai biomaterial sintesis adalah biokeramik. Belakangan ini keramik tidak hanya digunakan sebagai komponen kendaraan bemotor, peralatan rumah tangga, bahan bangunan dan lain-lain. Namun teknologi keramik telah diarahkan sebagai bahan penambahan dan rehabilitasi jaringan.

Di dalam bahan biokeramik tersebut dikenal dengan adanya bahan bioaktif (ion $\mathrm{Ca}^{2+}$ ). Bahan bioaktif tersebut adalah bahan yang dapat menimbulkan respon biologis spesifik pada pertemuan bahan dengan jaringan yang akan menimbulkan proses pembentukan tulang (osteogenesis) antara bahan dengan jaringan. Berbeda dengan bahan bio pada umumnya yang merupakan material inert karena hampir tidak beraksi dengan jaringan tubuh, bahan bioaktif mempunyai kemampuan untuk terikat secara langsung dengan tulang. Keuntungan material ini lebih stabil sebagai bahan implant dan lebih tahan lama (Vallet et al., 2004 and Carter et al., 2007).

Kalsium fosfat $(\mathrm{CaP})$ merupakan suatu subjek yang menarik dari beberapa penelitian ilmiah dikarenakan aplikasinya yang luas sebagai pengganti tulang dan gigi dalam bentuk keramik dan polimer matriks komposit (Chong Liang et al., 2004). Penelitian ini dilakukan pemanfaatan batu kapur dengan mengolahnya menjadi bahan baku pada sintesis kalsium fosfat yaitu sebagai sumber kalsium. Dari semua daerah penghasil batu kapur tersebut, batu kapur Bukit Tui, Kota Padang Panjang merupakan daerah yang paling banyak pemanfaatan potensi batu kapurnya. Potensi 
batu kapur Bukit Tui di Padang Panjang memiliki kandungan unsur kimia yaitu $\mathrm{CaO}$ $(52,32-57,45 \%), \mathrm{MgO}(0,96-4,55 \%), \mathrm{Fe}_{2} \mathrm{O}_{3}$ $(0,32-2,47 \%)$ dan $\mathrm{SiO}_{2}(0,49-1,52 \%)$ (Dinas Energi dan Sumber Daya Mineral Propinsi Sumatera Barat, 2008).

Berbagai metode telah dikembangkan untuk sintesis kalsium fosfat. Pada umumnya sintesis partikel kalsium fosfat menggunakan metode reaksi fase padat yang merupakan proses yang relatif sulit untuk menghasilkan material dengan komposisi yang homogen dan ukuran yang seragam. Disamping itu metode ini membutuhkan reaksi pada suhu tinggi lebih dari $1000^{\circ} \mathrm{C}$ dan waktu reaksi yang lama (Kottaisamy et al., 1997). Metode lain yang digunakan adalah metode proses liquid diantaranya metode sol-gel. Sehingga pada penelitian ini digunakan metoda pelapisan dipcoating melalui proses sol gel untuk menghasilkan senyawa kalsium fosfat yang homogen dan ukuran yang seragam.

Dalam penelitian ini digunakan batu kapur bukit tui sebagai sumber kalsium dan diammonium hidrogen fosfat sebagai sumber fosfat serta melihat perubahan struktur dan morfologi yang dihasilkan dengan variasi ratio molar $\mathrm{Ca} / \mathrm{P} 1,5 ; 1,6 ; 1,67 ; 1,7$ dan 1,8.

\section{METODE PENELITIAN}

Sampel hasil kalsinasi batu kapur bukit tui $(\mathrm{CaO})$ ditimbang sebanyak 2,8 $\mathrm{g}(0,05 \mathrm{~mol})$ dilarutkan dengan $50 \mathrm{ml}$ etanol dan $7 \mathrm{ml} \mathrm{HNO}_{3}$. Larutan distirer selama 30 menit dengan suhu $50^{\circ} \mathrm{C}$ sehingga didapatkan suspensi. Tambahkan DEA perlahan-lahan sebanyak 9,6 mL sambil distirer $(\mathrm{Ca}: \mathrm{DEA}=1: 2)$, lanjutkan stirrer hingga 3 jam. Larutan CaDEA yang telah larut tersebut disaring dengan corong Buchner menggunakan pompa vakum sehingga didapatkan larutan filtrat.

Larutan diammonium hidrogen fosfat dibuat dengan perbandingan rasio molar $\mathrm{Ca} / \mathrm{P}$ 1,$5 ; 1,6 ; 1,67 ; 1,7$ dan 1,8. Larutan tersebut ditambahkan ke dalam larutan filtrat secara perlahan dengan menggunakan buret dan di stirer dengan kecepatan $700 \mathrm{rpm}$ pada suhu $25^{\circ} \mathrm{C}$. Ukur $\mathrm{pH}$ larutan dengan menggunakan kertas $\mathrm{pH}$. Stirrer dilakukan selama 4 jam hingga terbentuk sol.
Sol yang didapatkan dari berbagai variasi rasio molar $\mathrm{Ca} / \mathrm{P}$ dkeringkan pada suhu $135^{\circ} \mathrm{C}$ selama 3 jam untuk menguapkan pelarut etanolnya hingga didapatkan gel. Kemudian dikalsinasi suhu $950^{\circ} \mathrm{C}$ hingga terbentuk powder putih. Terhadap powder-powder yang didapat, dilakukan analisa FTIR dan XRD sebagai analisis awal untuk mengidentifikasi senyawa kalsium fosfat yang terbentuk. Selanjutnya hasil dari analisis XRD akan digunakan untuk proses pembuatan lapisan tipis.

Proses pelapisan dilakukan pada plat kaca yang sebelumnya telah dibersihkan dengan aquades, di bilas dengan etanol dan di keringkan pada suhu $110^{\circ} \mathrm{C}$ selama 15 menit. Pelapisan dilakukan dengan mencelupkan plat kaca kedalam sol (pada suhu kamar $25^{\circ} \mathrm{C}$ ), kemudian plat kaca ditarik dengan peralatan dip-coating dengan kecepatan $20 \mathrm{~cm} /$ menit. Plat kaca yang telah dilapisi di keringkan pada suhu $110^{\circ} \mathrm{C}$ selama 15 menit. Proses pelapisan dilakukan berulang sebanyak tiga kali untuk mendapatkan ketebalan yang cukup untuk di karakterisasi dan kemudian dipanaskan pada suhu $400^{\circ} \mathrm{C}$ selama 1 jam. Setelah itu akan terbentuk lapisan tipis putih pada plat kaca.

Karakterisasi FTIR pada sampel powder dilakukan untuk menentukan gugus fungsi senyawa kalsium fosfat yang terbentuk. Sedangkan analisis dengan X-Ray Diffraction (XRD) untuk menentukan struktur dan ukuran kristal yang terbentuk dan scanning electron microscopy (SEM) untuk menentukan morfologi permukaan sampel dilakukan pada sampel powder dan lapisan tipis.

\section{HASIL DAN PEMBAHASAN}

Hasil analisis komposisi kimia batu kapur Bukit Tui dengan menggunakan XRF dapat dilihat pada Tabel 1. Hasil analisis XRF menunjukkan bahwa kandungan $\mathrm{CaO}$ dalam sampel batu kapur adalah lebih dari 50\% sehingga dapat digunakan sebagai bahan dasar dalam pembuatan senyawa kalsium fosfat. Karena batu kapur yang memiliki kualitas yang baik itu adalah yang memiliki kandungan $\mathrm{CaO}$ minimal 50\% (Hassibi, 1993). 
Lia Anggresani, DIP-Coating Senyawa Kalsium Fosfat dari Batu Kapur Bukit Tui

Tabel 1 Komposisi Kimia dari Batu Kapur Bukit Tui Padang Panjang

\begin{tabular}{cc}
\hline Senyawa & Komposisi Kimia (\%) \\
\hline $\mathrm{CaO}$ & 53,15 \\
$\mathrm{SiO}_{2}$ & 2,70 \\
$\mathrm{Al}_{2} \mathrm{O}_{3}$ & 0,87 \\
$\mathrm{MgO}$ & 0,75 \\
$\mathrm{Fe}_{2} \mathrm{O}_{3}$ & 0,58 \\
$* \mathrm{LOI}$ & 42,55 \\
\hline
\end{tabular}

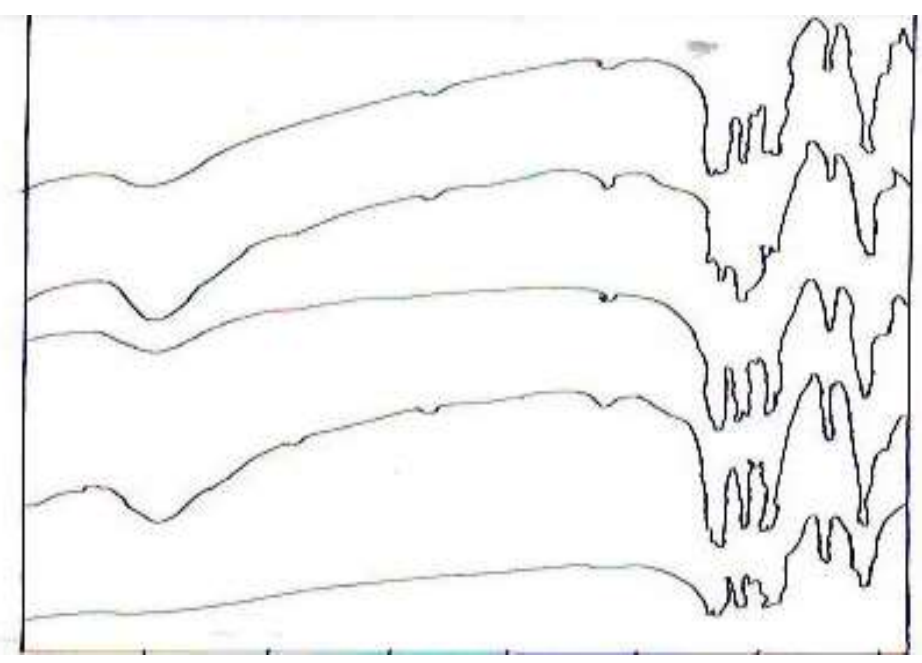

Gambar 1. Spektrum FTIR Powder Kalsium Fosfat dengan Variasi Ratio Mol (a) $\mathrm{Ca} / \mathrm{P} 1,5$ (b) $\mathrm{Ca} / \mathrm{P} 1,6$ (c) $\mathrm{Ca} / \mathrm{P} 1,67$ (d) $\mathrm{Ca} / \mathrm{P} 1,7$ dan (e) $\mathrm{Ca} / \mathrm{P} 1,8$

Apabila persentase $\mathrm{CaO}$ dikonversikan berdasarkan kandungan oksida logam saja tanpa gas karbondioksida, maka kandungan $\mathrm{CaO}$ dalam batu kapur adalah 91,60\%. Jumlah ini tidak jauh berbeda jika kita memakai sumber kalsium sintesis seperti kalsium asetat sintesis dengan kadar Ca sekitar 90\% (Jamarun et al., 2010).

Analisis awal dilakukan terhadap sampel powder kalsium fosfat pada variasi ratio molar $\mathrm{Ca} / \mathrm{P} 1,50 ; 1,60 ; 1,67 ; 1,70$ dan 1,80 seperti yang terdapat pada Gambar 1. Dimana dari hasil analisis dengan variasi ratio $\mathrm{mol} \mathrm{Ca} / \mathrm{P} 1,5$, memperlihatkan pada daerah sekitar 491 dan $567 \mathrm{~cm}^{-1}$ merupakan daerah bending P-O pada gugus $\mathrm{PO}_{4}^{-3}$ dan pada daerah sekitar 968, 1024, 1078, 1162, $1215 \mathrm{~cm}^{-1}$ merupakan daerah stretching $\mathrm{P}-\mathrm{O}$ pada gugus $\mathrm{PO}_{4}^{-3}$. Sedangkan pada daerah $1641 \mathrm{~cm}^{-1}$ merupakan daerah bending molekul air. Selain itu pada daerah 727 $\mathrm{cm}^{-1}$ ditemukan gugus $\mathrm{P}_{2} \mathrm{O}_{7}{ }^{-4}$ seperti pola spektum yang didapatkan oleh Utami et al dimana mendapatkan pola spectrum FTIR yang sama pada pembuatan senyawa kalsium fosfat yaitu adanya gugus $\mathrm{P}_{2} \mathrm{O}_{7}^{-4}$ pada daerah sekitar $726 \mathrm{~cm}^{-1}$.

Spektrum FTIR dengan variasi ratio mol $\mathrm{Ca} / \mathrm{P}$ 1,6 dan $\mathrm{Ca} / \mathrm{P}$ 1,67 memperlihatkan pada daerah sekitar $569^{\circ} \mathrm{cm}^{-1}$ merupakan daerah bending $\mathrm{P}-\mathrm{O}$ pada gugus $\mathrm{PO}_{4}^{-3}$ dan pada daerah sekitar $965^{\circ}, 1025^{\circ}, 1081^{\circ}, 1159^{\circ}, 1209^{\circ} \mathrm{cm}^{-1}$ merupakan daerah stretching $\mathrm{P}-\mathrm{O}$ pada gugus $\mathrm{PO}_{4}^{-3}$. Sedangkan pada daerah $3461^{\circ} \mathrm{cm}^{-1}$ merupakan daerah stretching $\mathrm{O}-\mathrm{H}$ dari air dan pada daerah sekitar $1639^{\circ} \mathrm{cm}^{-1}$ merupakan daerah bending molekul air. Selain itu juga ditemukan gugus $\mathrm{P}_{2} \mathrm{O}_{7}^{-4}$ pada $726^{\circ} \mathrm{cm}^{-1}$ yang menunjukkan teramatinya gugus kalsium fosfat. 
Analisis FTIR pada variasi ratio mol $\mathrm{Ca} / \mathrm{P} 1,7$ dan 1,8 memperlihatkan pada daerah sekitar $566^{\circ} \mathrm{cm}^{-1}$ merupakan daerah bending $\mathrm{P}$ $\mathrm{O}$ pada gugus $\mathrm{PO}_{4}^{-3}$, dan pada daerah $972^{\circ}$, $1071^{\circ}, 1158^{\circ}, 1212^{\circ} \mathrm{cm}^{-1}$ yang merupakan daerah stretching $\mathrm{P}-\mathrm{O}$ pada gugus $\mathrm{PO}_{4}^{-3}$. Sedangkan pada daerah $1640^{\circ}$ dan $3456^{\circ} \mathrm{cm}^{-1}$ merupakan daerah serapan O-H molekul air dan pada daerah sekitar $2358^{\circ} \mathrm{cm}^{-1}$ merupakan daerah $\mathrm{CO}_{2}$ dan ditemukan juga gugus $\mathrm{P}_{2} \mathrm{O}_{7}^{-4}$ pada $727^{\circ} \mathrm{cm}^{-1}$ yang menunjukkan teramatinya gugus kalsium fosfat. Dari kelima spectrum FTIR ini didapatkan kesamaan dengan hasil FTIR dari penelitian Costa Hermes et al (2007) yang melakukan karakterisasi pengcoatingan kalsium fosfat (Lampiran 5).

Hasil pengukuran XRD dilakukan pada sampel powder kalsium fosfat dengan variasi ratio molar $\mathrm{Ca} / \mathrm{P} 1,5 ; 1,6$; 1,67 dan 1,8 seperti yang ditunjukkan pada Gambar 2. Hasil pengukuran XRD menunjukkan didapatkan puncak-puncak yang sama dengan JCPDS -
712123 dimana puncak ini merupakan puncak Kalsium Fosfat $\mathrm{Ca}_{2} \mathrm{P}_{2} \mathrm{O}_{7}$. Puncak yang tajam dengan intensitas yang tinggi terdapat pada sudut $2 \theta=29,58^{\circ}$ dan adanya puncak-puncak lain dengan intensitas yang lebih rendah pada sudut $2 \theta=28,9^{\circ} ; 27,68^{\circ} ; 26,66^{\circ}$ dan $30,2^{\circ}$. Sesuai dengan data pada JCPDS 71-2123, maka produk yang terbentuk adalah $\mathrm{Ca}_{2} \mathrm{P}_{2} \mathrm{O}_{7}$ (Kalsium Fosfat).

Pola difraksi sinar-X juga dapat memberikan informasi mengenai ukuran kristal. Ukuran kristal ini bisa diketahui dengan menggunakan metode Scherrer, dimana puncak yang tajam dengan lebar puncak yang sempit menandakan bahwa ukuran kristal besar, sedangkan puncak yang mengalami pelebaran menandakan ukuran kristal kecil. Dengan mengukur FWHM (Full Width at Half Maximum) dari puncak dengan refleksi tertinggi (Gambar 2), diperoleh ukuran kristalnya sebesar $28 ; 29$; 21 dan $31 \mathrm{~nm}$ (lihat pada Tabel 2).

Tabel 2. Ukuran kristal senyawa kalsium fosfat berdasarkan Scherrer's Formula

\begin{tabular}{cccc}
\hline Ratio mol Ca/P & $2 \theta\left(^{\circ}\right)$ & FWHM $\left(^{\circ}\right)$ & Ukuran Kristal $(\mathrm{L}) \mathrm{nm}$ \\
\hline 1,5 & 29,615 & 0,282 & 28 \\
1,6 & 29,591 & 0,279 & 29 \\
1,67 & 29,668 & 0,385 & 21 \\
1,7 & 29,652 & 0,382 & 21 \\
1,8 & 29,813 & 0,262 & 31 \\
Lap. Tipis & 29,500 & 0,180 & 45 \\
\hline
\end{tabular}

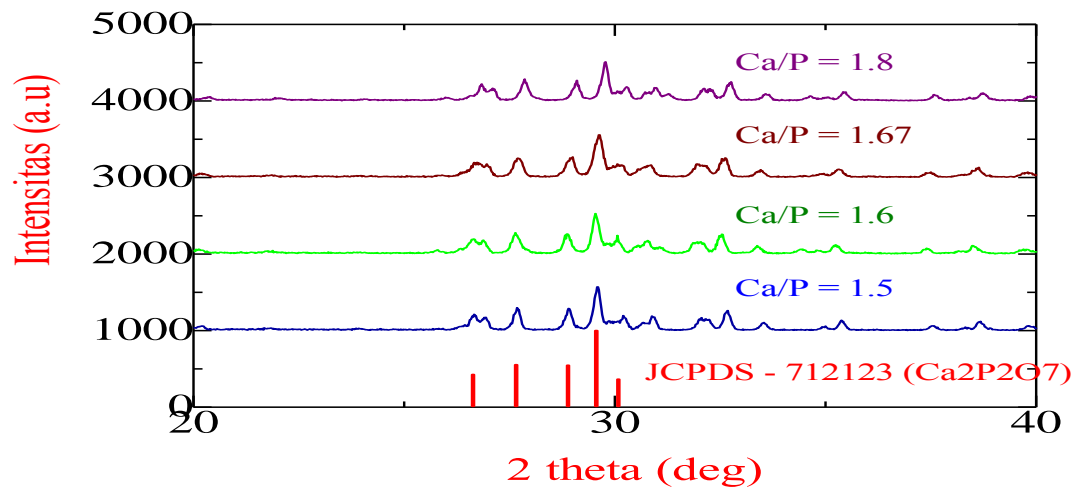

Gambar 2 Pola XRD Powder Kalsium Fosfat dengan Variasi Ratio Mol $\mathrm{Ca} / \mathrm{P} 1,5 ; 1,6 ; 1,67$ dan 1,8 
Lia Anggresani, DIP-Coating Senyawa Kalsium Fosfat dari Batu Kapur Bukit Tui

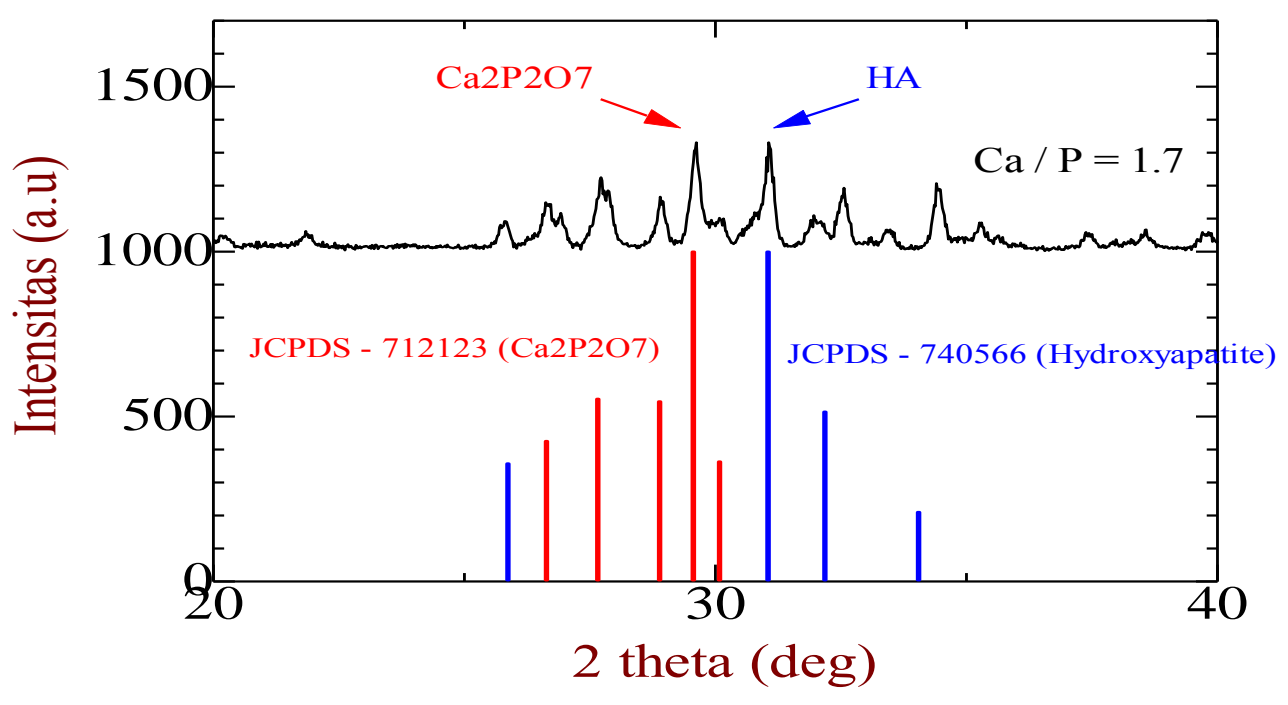

Gambar 3. Pola XRD Powder Kalsium Fosfat dengan Variasi Ratio Mol Ca/P 1,7

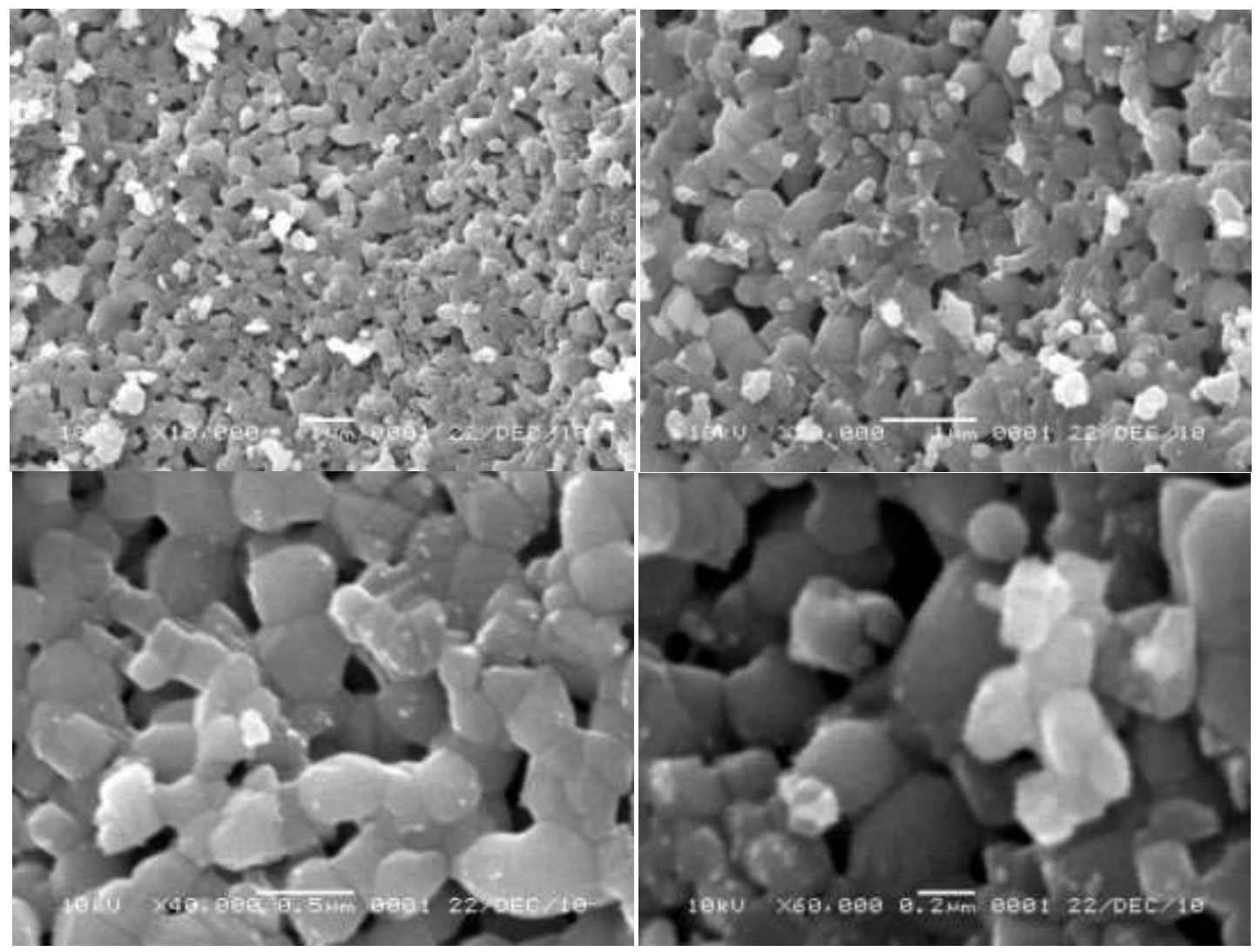

Gambar 4 Mikrograf SEM terhadap Powder Senyawa Kalsium Fosfat

Hasil XRD dengan variasi ratio $\mathrm{mol} \mathrm{Ca} / \mathrm{P}$ 1,7 ditunjukkan pada gambar 3 didapatkan senyawa Hydroxyapatite $\mathrm{Ca}_{10}\left(\mathrm{PO}_{4}\right)_{6}(\mathrm{OH})_{2}$ dan Kalsium Fosfat $\mathrm{Ca}_{2} \mathrm{P}_{2} \mathrm{O}_{7}$ dengan merujuk pada 
JCPDS - 740566 dan JCPDS 712123. Puncakpuncak Hydroxyapatite ditunjukkan pada sudut $2 \theta=31,07^{\circ} ; 25,80^{\circ} ; 32,56^{\circ} ; 34,40^{\circ} ; 52,88^{\circ}$. Sedangkan puncak Kalsium Fosfat ditunjukkan pada sudut $2 \theta=29,62^{\circ} ; 26,62^{\circ}$ dan $27,72^{\circ}$. Disini didapatkan perbedaan struktur yang dihasilkan pada gambar 4 dan gambar 5, hal ini disebabkan adanya pengaruh perbandingan mol $\mathrm{Ca} / \mathrm{P}$ dimana untuk mendapatkan senyawa kalsium fosfat sangat tergantung pada temperatur dan $\mathrm{pH}$. Dan ukuran kristal yang didapatkan pada $\mathrm{Ca} / \mathrm{P}$ 1,7 ini adalah sebesar 21 nm (lihat pada Tabel 2).

Analisa SEM pada penelitian ini hanya dilakukan terhadap variasi ratio mol $\mathrm{Ca} / \mathrm{P} 1,7$. Dilakukannya analisis SEM ini didasarkan pada hasil analisis sampel powder XRD yang telah didapatkan, dimana didapatkannya dua struktur yaitu Hydroxyapatite $\mathrm{Ca}_{10}\left(\mathrm{PO}_{4}\right)_{6}(\mathrm{OH})_{2}$ dan Kalsium Fosfat $\mathrm{Ca}_{2} \mathrm{P}_{2} \mathrm{O}_{7}$. Gambar 4 menunjukkan foto SEM dari powder senyawa kalsium fosfat. Perbesaran yang digunakan dalam foto SEM ini adalah 10.000, 20.000, 40.000 dan 60.000 kali. Dapat dilihat powder senyawa kalsium fosfat berbentuk spherical dan memiliki distribusi partikel yang merata dan rapat. Distribusi ukuran partikel berkisar antara $0,25-0,75 \mu \mathrm{m}$.
Pada hasil XRD lapisan tipis hanya didapatkan 1 puncak. Ini menandakan bahwa ada indikasi kristal walaupun belum sempurna. Menurut Tkalcec et al, ketika sampel kalsium fosfat dikalsinasi pada $400^{\circ} \mathrm{C}$ maka struktur yang dihasilkan akan berbentuk amorf, sedangkan pada $535^{\circ} \mathrm{C}$ akan menghasilkan kristal $\beta$-tri-calcium phosphate $(\beta$-TCP) dan kristal hydroxyapatite (Tkalcec. E. et al., 2001) dimana pembakaran lapisan tipis ini dilakukan pada $400^{\circ} \mathrm{C}$.

Dapat dilihat dari gambar 5 adanya puncak tersebut berada pada $2 \theta=29,50^{\circ}$ dimana puncak ini menunjukkan puncak Calsium Fosfat sesuai dengan JCPDS - 712123. Dari pola XRD ini masih banyaknya noise, hal ini dapat disebabkan oleh pengaruh suhu yang dilakukan pada saat melakukan pembakaran (furnace) sampel lapisan tipis. Pembakaran (pengkalsinasian) dilakukan pada suhu $400^{\circ} \mathrm{C}$ dimana pada suhu ini masih adanya karbon yang terikat pada sampel. Jika pembakaran (pengkalsinasian) dilakukan pada suhu diatas $400^{\circ} \mathrm{C}$ dikhawatirkan plat kaca (glass) yang digunakan untuk melapisi sampel akan meleleh. Oleh sebab itu pembakaran (pengkalsinasian) dilakukan pada suhu $400^{\circ} \mathrm{C}$ dan didapatkan juga ukuran kristal sebesar $45 \mathrm{~nm}$ (lihat pada tabel 2).

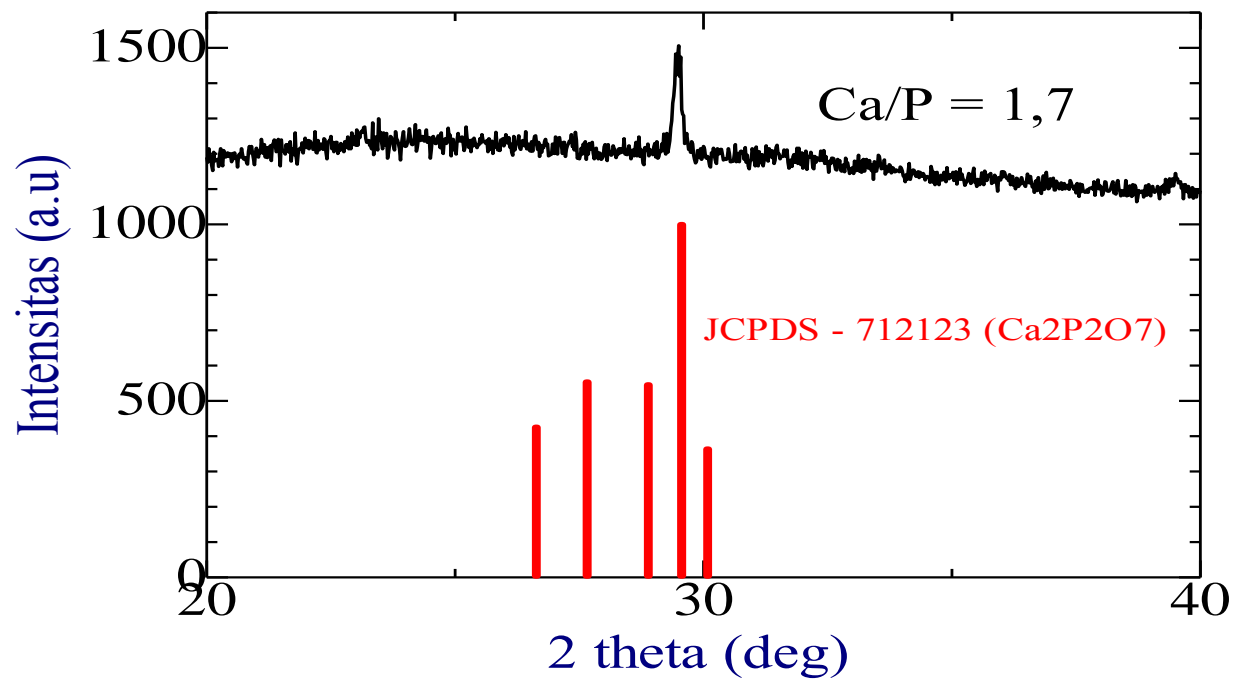

Gambar 5 Pola XRD Lapisan Tipis Kalsium Fosfat dengan Ratio mol Ca/P 1,7 
Gambar 6 menunjukkan foto SEM lapisan tipis senyawa kalsium fosfat tampak dari muka. Pembesaran yang dilakukan pada foto SEM ini adalah 1.000, 20.000 dan 40.000 kali. Dapat dilihat pada permukaan lapisan tipis ini sebaran partikel kurang merata dengan adanya sedikit bongkahan dan bongkahan itu ketika diperbesar memperlihatkan bentuk yang seperti bunga. Adanya sedikit bongkahan pada permukaan lapisan tipis ini disebabkan oleh pada saat melakukan coating masih adanya partikel yang tidak homogeny sehingga pada proses pemanasan terjadi penggumpalan. Distribusi ukuran partikel berkisar antara 0,11 $3,7 \mu \mathrm{m}$. Fasa kristal Hydroxyapatite hanya terbentuk pada pemanasan suhu $1200^{\circ} \mathrm{C}$. Bagaimanapun pengendapan dengan cepat selama titrasi larutan fosfat menunjukkan ketidakhomogenan produk akhir. Titrasi yang lambat harus dilakukan untuk menghasilkan kehomogenan dan stoikiometri dari hasil hydroxyapatite (Liu, Dean-Mo et al., 2001).

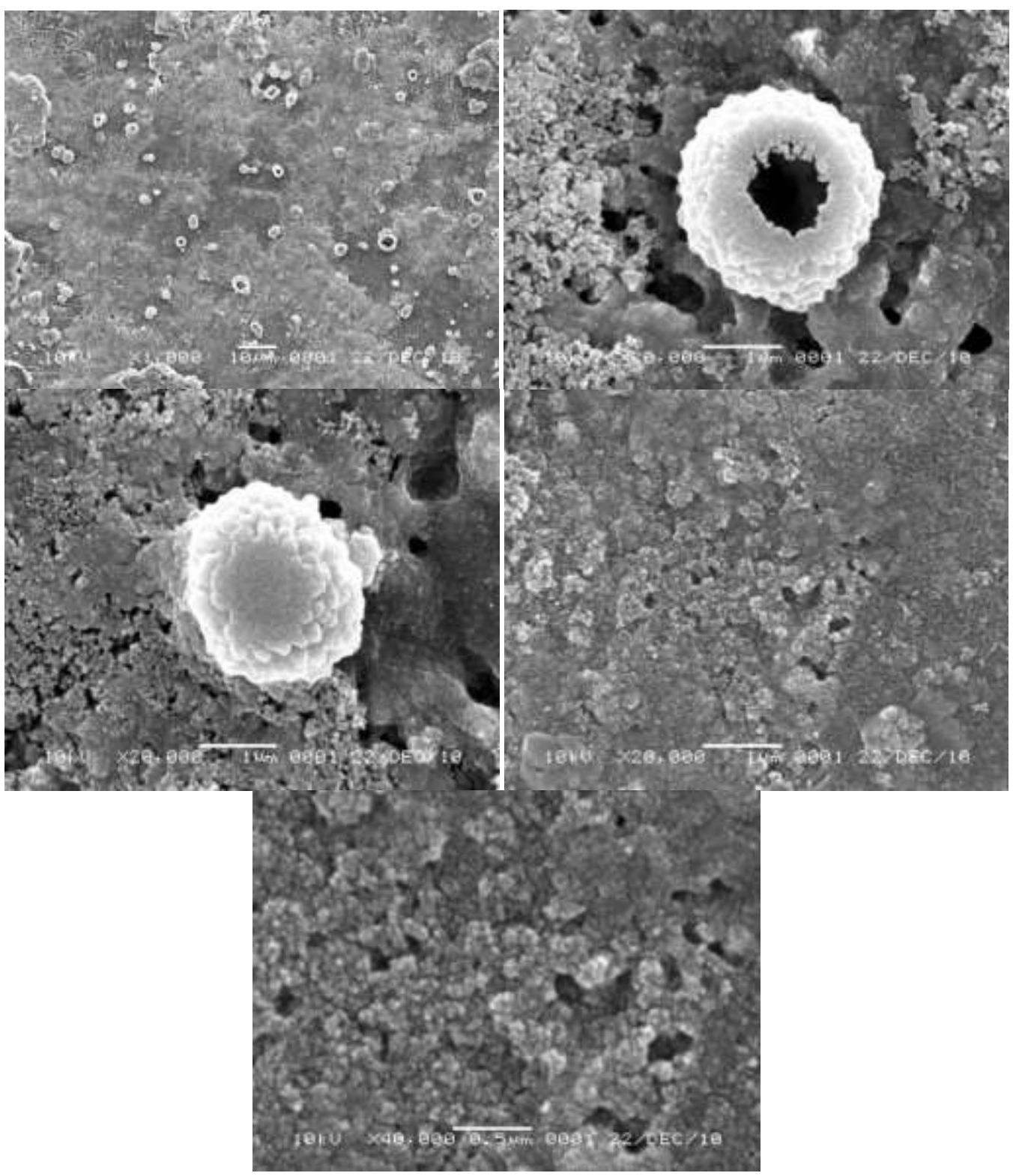

Gambar 6 Mikrograf SEM terhadap Lapisan Tipis Senyawa Kalsium Fosfat 

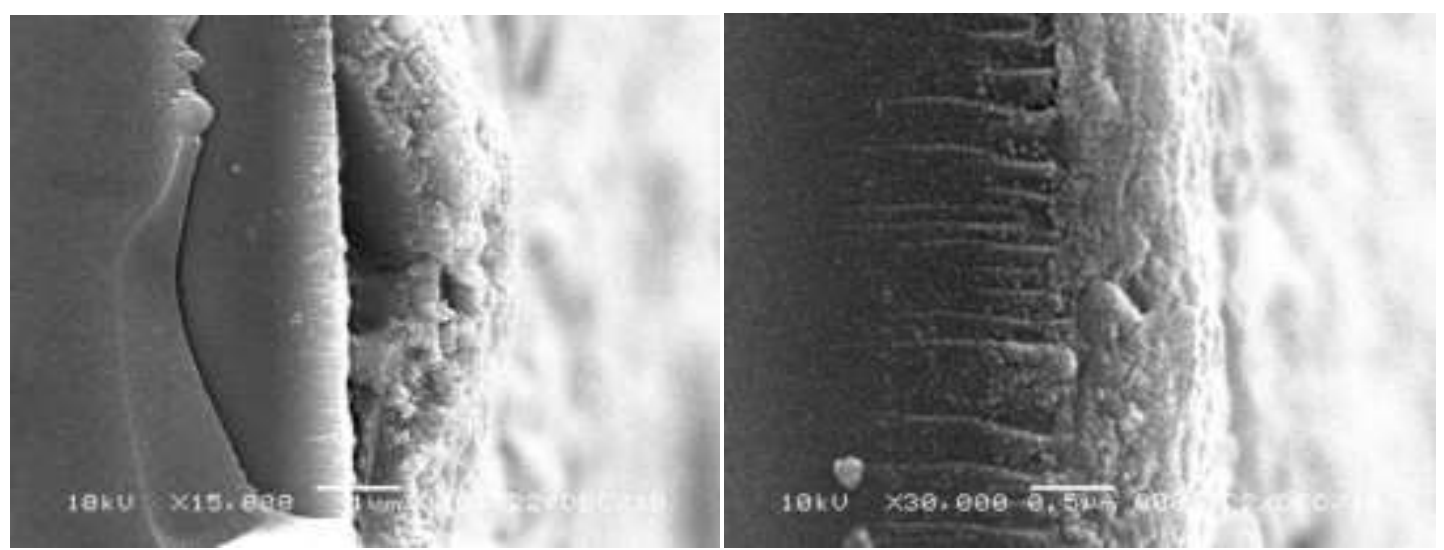

Gambar 7 Mikrograf SEM cross section lapisan tipis senyawa kalsium fosfat

Gambar 7 menunjukkan foto SEM cross section lapisan tipis senyawa kalsium fosfat tampak dari samping. Pembesaran yang dilakukan pada lapisan tipis ini adalah 15.000 dan 30.000 kali. Dapat dilihat sebaran partikel yang merata dan adanya bongkahan yang seperti bunga pada pembesaran 15.000 kali. Distribusi ukuran partikel berkisar antara 0,78 $2,1 \mu \mathrm{m}$.

Dapat dilihat dari hasil SEM powder berbeda dengan hasil SEM lapisan tipis. Hal ini disebabkan karena pada powder pengkalsinasian dilakukan pada suhu $950^{\circ} \mathrm{C}$ sedangkan pada lapisan tipis pengkalsinasian dilakukan pada suhu $400^{\circ} \mathrm{C}$ sehingga pada lapisan tipis masih adanya karbon yang melekat pada kaca yang menyebabkan hasil SEM yang kurang bagus dibandingkan hasil SEM powder.

\section{KESIMPULAN}

Pembuatan senyawa kalsium fosfat dapat dibuat dengan menggunakan batu kapur Bukit Tui sebagai precursor kalsium dan diammonium hydrogen fosfat sebagai precursor fosfat dengan metode sol-gel. Dari Pola XRD powder didapatkan struktur Kalsium Fosfat dan pada variasi ratio $\mathrm{mol} \mathrm{Ca/P} \mathrm{1,7} \mathrm{didapatkan} \mathrm{juga}$ struktur lain yaitu Hydroxyapatite (HA) sedangkan dari pola XRD lapisan tipis didapatkan 1 puncak yang mengindikasikan adanya kristal Kalsium Fosfat walaupun belum sempurna. Hasil powder SEM memperlihatkan kalsium fosfat yang berbentuk spherical dan memiliki distribusi partikel yang merata serta rapat sedangkan hasil lapisan tipis memperlihatkan sebaran partikel kurang merata dan sedikit bongkahan.

\section{DAFTAR KEPUSTAKAAN}

Carter C. B, dan Norton M. G, 2007. Ceramic Materials, Science and Engineering, Springer Science Business Media, LLC, New York, pp 644-645.

Chong Liang, Zhaoyang Li, De'an Yang, Yuanyuan Li, Zi Yang, and William W. $\mathrm{Lu}, 2004$, Synthesis of Calsium Phosphate / Calsium Sulphate Powder, J. Materials Chemistry and Physics, 88, pp 285-289.

Costa Hermes de Souza, Pereira Magalhaes Marivalda, Mansur Herman Sander, 2007, Characterization of Calsium Phosphate Coating and Zinc Incorporation on the Porous Alumina Scaffolds, Materials Research Vol 10, 1, pp : 27-29.

Dinas Energi dan Sumber Daya Mineral Provinsi Sumatera Barat. 2008. Informasi Potensi Sumber Daya Mineral dan Energi Provinsi Sumatera Barat.

Hassibi M, 1993, Factors Affecting Quality of $\mathrm{CaO}, \quad 3^{\text {rd }}$ International Sorbalyt Symposium, New Orleans, USA.

Jamarun Novesar, Harmileni dan Arief Syukri, 2010, Sintesis Senyawa Apatite Dengan Menggunakan Batu Kapur Sebagai 
Sumber Kalsium. Proseding Semirata PTN Barat, 1, pp 770 -777.

Kottaisamy M, Jagannathan R, Jeyagopal P, Rao R. P, dan Narayanan R. L, 1994, $\mathrm{Eu}^{2+}$ luminescence in $\mathrm{M}_{5}\left(\mathrm{PO}_{4}\right)_{3} \mathrm{X}$ apatites, where $\mathrm{M}$ is $\mathrm{Ca}^{2+}, \mathrm{Sr}^{2+}$ and $\mathrm{Ba}^{2+}$, and $\mathrm{X}$ is $\mathrm{F}^{-}, \mathrm{Cl}^{-}, \mathrm{Br}^{-}$and $\mathrm{OH}^{-}, J$. Phys. D, 27, pp $2210-2215$.

Liu Dean-Mo, Troczynski T, and Tseng Wenjea T, 2001, Water-based Sol-Gel Synthesis of Hydroxyapatite : Process Development, Biomaterials, 22 , pp 1721-1730.
Tkalcec E, Sauer M, Nonninger R, and Schmidt H, 2001, Sol-Gel-Derived Hydroxyapatite Powders and Coating, Journal of Materials Science, pp 52535263.

Utami Lisa, 2010, Pengaruh Kondisi Kalsinasi dan Penggunaan Prekursor yang Berbeda Pada Sintesis Senyawa Kalsium Fosfat Melalui Metode Pengendapan. Tesis. Padang. Universitas Andalas.

Vallet R. M, dan Gonzalez C. J. M, 2002, Calcium phosphates as substitution of bone tissues, Prog.Solid St.Chem, 32, pp $1-31$. 